\title{
The Population of Mangrove Clam (Polymesoda expansa) in The Panikel Village, Segara Anakan, Cilacap
}

\author{
Widianingsih Widianingsih", Ria Azizah Tri Nuraini, Ita Riniatsih, Retno Hartati, Sri \\ Redjeki, Hadi Endrawati, Elsa Lusia Agus, and Robertus Triaji Mahendrajaya \\ Department of Marine Sciences, Faculty Fisheries and Marine Sciences, Diponegoro University, Jl. \\ Prof. Sudharto, Tembalang, Semarang, Central Java, Indonesia
}

\begin{abstract}
Mangrove clam Polymesoda expansa belonged to the family Corbiculidae. The clam itself is a semi-infauna that lives partially below the soft sediment around the roots of mangrove trees. The purpose of this research is to study the population $P$. expansa in Panikel Area, Segara Anakan, Cilacap. The size of the sampling site for this research was $10 \times 10$ $\mathrm{m}$. Mangrove clam $P$. expansa was taken by handpicking. Sampling was conducted in April and June 2019. The water quality parameters were taken in-situ. According to the research result, the highest population of $P$. expansa in Panikel occurred in June amounting to 85 individuals. In the Panikel area, $P$. expansa has a positive correlation between the total weight and shell length not only in April but also in June. It can be concluded that the mangrove area in Panikel Village is suitable for supporting $P$. expamsa population.
\end{abstract}

\section{Introduction}

Segara Anakan is one of the largest estuaries on Java Island. It is a mangrove shallow coastal lagoon located in South Central Java (108 $46^{\prime}$ E-109 $03^{\prime}$ ' E, $8^{\circ} 35^{\prime}$ S $-8^{\circ} 48^{\prime}$ S (Fig 1). It is separated from the Indian Ocean by the rocky mountainous Island of Nusakambangan [1]. The Segara Anakan Lagoon is facing serious degradation due to land conversion, illegal logging, and a high level of sedimentation rate [2]. There are three big rivers that were into Segara Anakan: Cintaduy, Cikonde, and Cimeneng [2,3]. The high sedimentation rate in Segara Anakan caused the formation of deltas that make Gombol islands, Nusa Alas, Nusa Parts and Nusa Lorokanbuntu. The amount of material that enters Segara Anakan through the mouth of the rivers resulted in its waters becoming rich in nutrients, hence it is a good place for the growth of benthic faunas. Polymesoda Environment is a benthic fauna that is associated with the mangrove ecosystem.

P. expansa is one of the species of mangrove clams belonging to family Corbiculidae, class Bivalvia, subclass Heterodonta [4]. There are four common species of mangrove clam in South-East Asia such as; Polymesoda expansa, Polymesoda erosa, Polymesoda bengalensis and Batissa violacea [5].

\footnotetext{
*Corresponding author: widia2506@gmail.com
} 
In Segara Anakan, the exploitation of $P$. expansa is massive. The clam is usually consumed by the local population. The data on the size of fishermen's catch is very minimal and not even recorded in the Marine and Fisheries Ministry. The minimal recorded data is caused by the lack of role of the relevant agencies. Generally, the local population still relies on catches from nature and the consumed stock was not supported by aquaculture. The mangrove clams are also sold to Jakarta and Bali.

Research on reproductive aspects is needed to study the development and population dynamics of $P$. expansa. Previous studies that has been conducted regarding the biology of mangrove clam in Segara Anakan including on the topic of mud clam (Polymesoda erosa) gonads histology from Segara Anakan [6], research on the effect of natural feed on fatty acid content in Polymesoda erosa [7], and also a study on the effect of salinity degradation on population structure and distribution of Polymesoda sp. (Geloina sp.) from Segara Anakan [8]. There were also recent studies about the ecology of macrobenthos particularly the ecology of the mangrove clam Polymesoda erosa [9, 10, 11, 12]. However, the research on Polymesoda expansa which includes population, reproduction aspect, gonad, reproduction and cultivation aspects has not been well explored. This study aims to investigate the population dynamics of Polymesoda expansa from Segara Anakan, Cilacap.

\section{Material and Methods}

Mangrove clam sampling was carried out in the mangrove area near Panikel village in April, June and August 2019 (Fig. 1.). The sampling site covers an area of $10 \times 10 \mathrm{~m}$. The samples were obtained using purposive sampling method. Clam samples were collected directly by handpicking. Measurements of water quality (salinity, temperature, dissolved oxygen, $\mathrm{pH}$ ) were carried out by a water quality checker. Nansen bottle was used to take water samples for measuring phosphate and nitrate concentration.

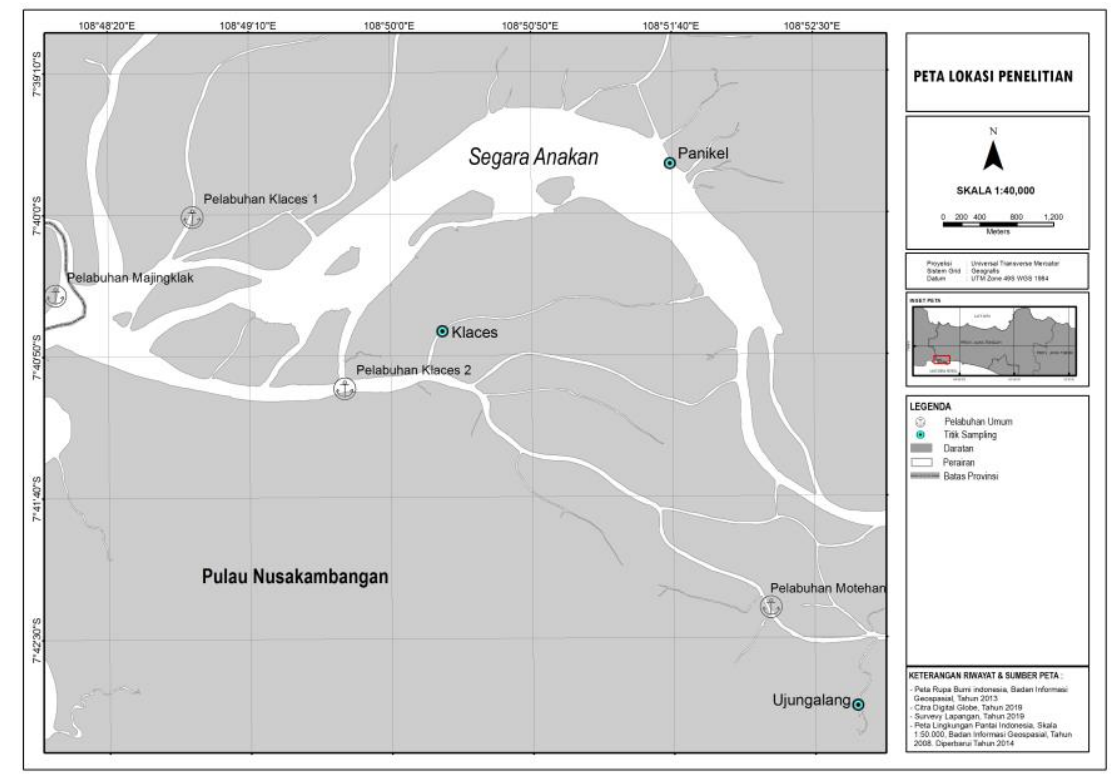

Fig.1. Sampling site of $P$. expansa around the area near Panikel village, Segara Anakan, Cilacap (Blue dots). 
Samples of $P$. expansa were taken and brought to the laboratory for identification using a reference book by Carpenter and Niem (1998) [13]. Total weight was measured using electronic scale. The measurement of shell width, shell height, shell length was carried out using electric calipers.

Female and male carapace width to total weight (W) relationships were analyzed using least square regression with the formula [14]:

$$
\mathrm{W}=\mathrm{a} \mathrm{L}^{\mathrm{b}}
$$

Condition factor relative was calculated using formula [14]:

$$
\mathrm{Cf}=\mathrm{W} / \mathrm{a} \mathrm{L}^{\mathrm{b}}
$$

\section{Result and Discussion}

The mangrove vegetation found around the Panikel area are Derris heterophilla, Achantus illicifolius, Bruguera sp., Aegiceras corniculatum, Nypa fruticans. Mangrove vegetations that are usually found in Segara Anakan included Rhizopora apiculata, Rhizopora mucronata, Derris heterophilla, Achantus illicifolius, Bruguera sp, Aegiceras corniculatum, Nypa fruticans, etc [8, 15].

Table 1. Water quality parameters in Panikel area, Segara Anakan Cilacap in 2019.

\begin{tabular}{lccc}
\hline \multicolumn{1}{c}{ Water Quality } & April & June & August \\
\hline Salinity (ppt) & $5-7$ & $5-6$ & $3-4$ \\
Dissolve Oxigen (ppt) & $6.78-7.82$ & $6.18-7.52$ & $6.76-784$ \\
Temperature ${ }^{\circ} \mathrm{C}$ & $29-30.80$ & $29-31$ & $29-32$ \\
Phosphate (ppm) & 0.0671 & 0.029 & 0.01 \\
Nitrate (ppm) & 0.2150 & 0.556 & 0.1159 \\
Depth (cm) & 25 & 20 & 10 \\
Substrate & Silt clay & Silt clay & Silt clay \\
\hline
\end{tabular}

The results of measurements of water quality parameters i.e. phosphate $(0.067 \mathrm{ppm})$ and nitrate $(0.215 \mathrm{ppm})$ are still in the high productivity threshold (Table 1). The high concentration of nitrate in the waters near the Panikel area might be influenced by the influx of water from the western rivers Citanduy and Cibereum. The nitrate concentration in the river water could stem from fertilizer usage in agricultural areas in the upland [1]. The salinity values measured were ranged from 5-7 ppt. The values are smaller than the measured salinity in the waters of Segara Anakan around July 2006 which was around 13-32 ppt [8]. The low salinity levels in the waters near Panikel was probably influenced by freshwater input from the Cibereum River. Although the waters are low in salinity, the density of mangrove plants still plays a role in the population of mangrove clams.

The measured temperature in the Panikel area waters was $29-31.5^{\circ} \mathrm{C}$. The result was correlated with measured temperature in the waters of Kendari Bay which is a habitat for mangrove clam P. erosa ranged around $28-32{ }^{\circ} \mathrm{C}$ [16]. Similar results were found with another research in Segara Anakan which showed that temperature for habitat mangrove clam had a range around $27-30.3{ }^{\circ} \mathrm{C}[8,15]$. For bivalves, the temperature is one of the factors that correspond with growth. Temperature plays a direct role in animal physiology processes, particularly to regulate metabolic processes and the reproductive cycle of the aquatic organisms $[15,16]$. 
According to the research result, the highest number of individuals $P$. expansa was found in June 2019 (85 individuals) and the lowest number of individuals were found in April 2019 amounting 33 individuals. Although 85 individuals were found in the sampling area in June, the shell sizes of $P$. expansa were smaller than those found in April (Fig. 2). This could indicate that the population of $P$. expansa underwent the recruitment process in the area. The average total weight in April (17.8 g) is greater than in June (8.44 g) (Fig. 3).

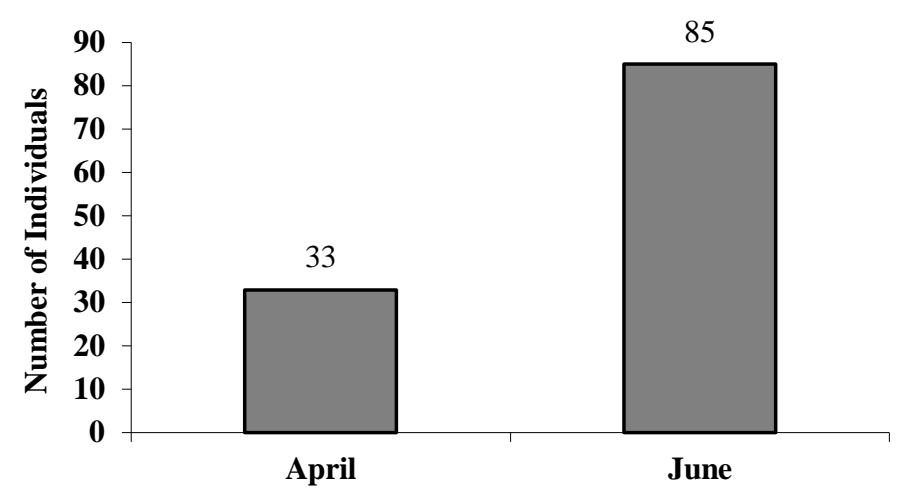

Fig. 2. Number of individuals P. expansa in Panikel Area in April and June 2019 in Segara Anakan, Cilacap.

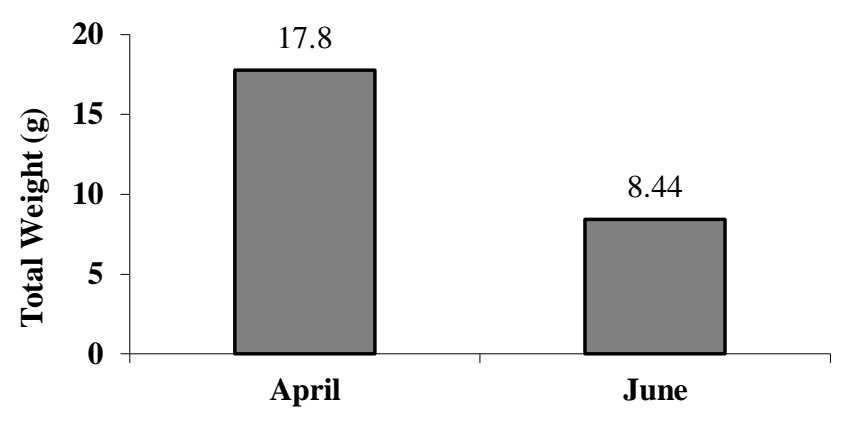

Fig. 3. The value of average Total Weight (g) in April and June, Panikel Segara Anakan Cilacap

The value of the average shell length on April was $4.59 \pm 0.79 \mathrm{~cm}$ and for June was 3.91 $\pm 0.31 \mathrm{~cm}$. The value of the average shell height in April $(4.26 \mathrm{~cm})$ was higher than in June $(3.6 \mathrm{~cm})$. Additionally, the value of the average shell width in April $(2.31 \mathrm{~cm})$ was higher than in June $(1.89 \mathrm{~cm})$. Although the number of $P$. expansa caught in June is higher than in April, the size of the shell in June is smaller than April (Fig. 4).

Based on the analysis of the relation between shell length and total weight, the growth pattern is allometric positive ( $b>3$ ) (Figure 4.). It means that the shell length increase is faster than the total weight. This could also indicate that the $P$. expansa population is still young and still continues to grow. The average value of the condition factor in April was $1.008 \pm 0.13$ and in June the condition factor was $1.005 \pm 0.92$. Large-sized clam groups have lower condition factor values [8]. The higher value of the condition factor in April compared to June was due to the gonad maturation process in $P$. expansa. 


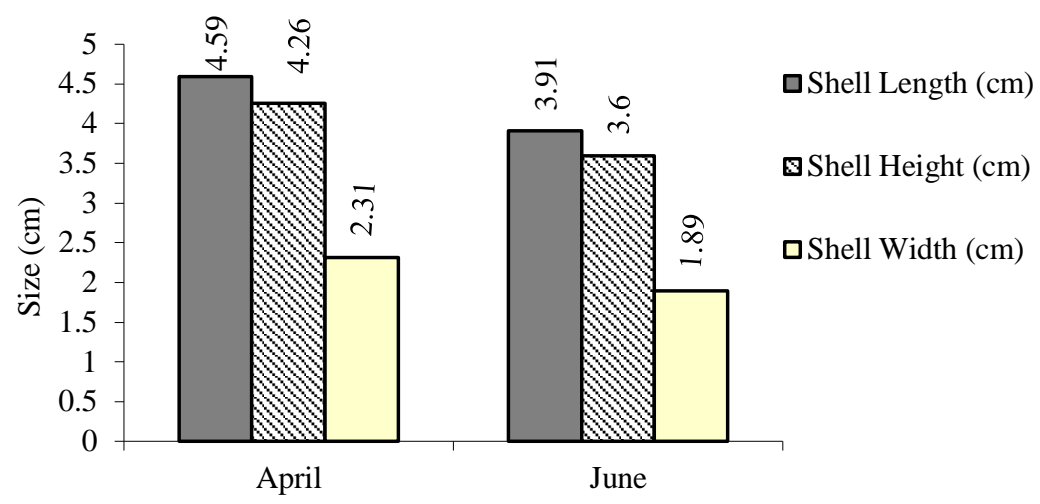

Fig. 4. Shell size of P. expansa in April and June 2019 at Panikel Area, Segara Anakan Cilacap.

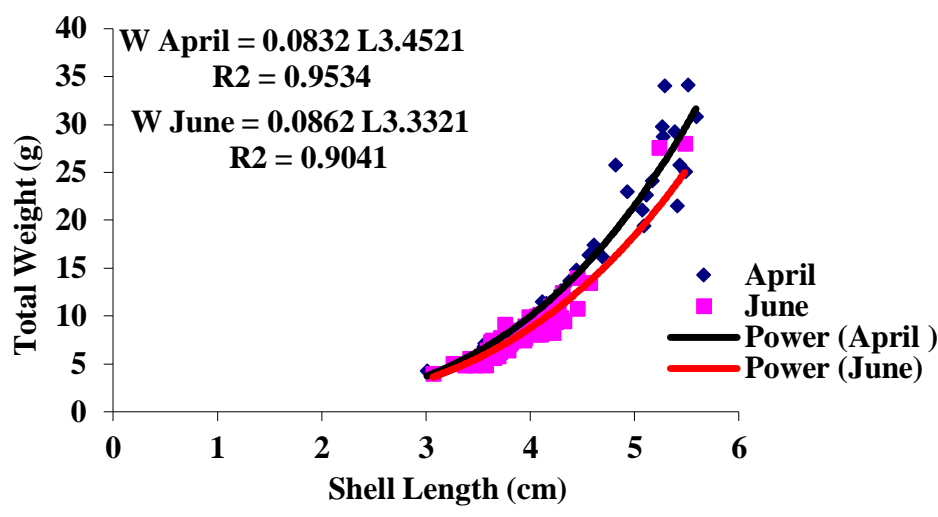

Fig. 5. The Relationship between shell length and the total weight of P. expansa, on April and June 2019 in Panikel area, Segara Anakan, Cilacap

The relationship between shell length and total weight were analyzed using least square regression. The relationship suggested that $P$. expansa that were caught in April had a faster total weight increase than in June as seen in Fig. 4. The growth pattern in April and June were allometric positive $(b>3)$. This shows that the shell width increased faster than the total weight gain. At the age of adulthood, the rate of shell size increase will be slower due to the age factor and the shells have reached the maximum size [8].

\section{Conclusion}

Based on the positive allometric growth pattern, it can be concluded that P.expansa populations for April and June showed positive results. The number of small $P$. expansa in June indicates a recruitment process that took place in the Panikel Area, Segara Anakan. $P$. expansa has a greater total weight and shell size in April than June. The population of $P$. expansa in the Panikel area still has positive growth and condition factor.

This research was funded by the Faculty of Fisheries and Marine Sciences of UNDIP through a Research grant. No. 25/UN7.5.10/PP/2019. we would like to thank all those who have helped in this research. 


\section{References}

1. E. Yuwono, T.C. Jannerjahn, I. Nordhaus, E.A. Riyanto, M.H. Sastranegara, R. Pribadi, Asian Journal of Water Environment and Pollution. 4(1): 61-70 (2007).

2. J. Heyde, M.C. Lukas, M. Flitner, Pembayaran Jasa Lingkungan: Instrumen baru untuk mengatasi masalah berkepanjangan di daerah aliran sungai dan pesisir di Indonesia. (2017). (In Indonesian)

3. R. Hartati, R. Pribadi, C.A. Suryono, Widianingsih, Indonesian Delta Forum Conference (2010).

4. T. Okutani, Marine mollusks in Japan. (Tokai University Press, 2000).

5. B. Morton, Asian Mar. Biol. 1, 77-86 (1984).

6. R. Hartati, I. Widowati, Y. Ristiadi. Ilmu Kelaut. Indones. J. Mar. Sci 10 (3): 199-125. (2005) (In Indonesian)

7. E. Supriyantini, I. Widowati, Ambariyanto, Ilmu Kelautan 12(2): 97-104 (2007).

8. I. Irwani, C.A. Suryono, Ilmu Kelaut. Indones. J. Mar. Sci. 11, 54-58 (2006).

9. R. Pribadi, Pus. Kaji. Pesisir dan Laut Trop. Lemb. Penelitian, Univ. Diponegoro, Semarang (2003).

10. C. A. Suryono, R. Pribadi, T. Sugiarto. Species composition and distribution of gastropoda in Segara Anakan mangrove forest, Cilacap. Center for Coastal and Marine Studies, Research Institute of Diponegoro University, Semarang (2003)

11. Widianingsih, C.A. Suryono, R. Pribadi, R. Hartati. Community structure of crustacea at mangrove area of Klaces and Sapuregel, Segara Anakan, Cilacap. (2003a).

12. Widianingsih, R. Hartati, C.A. Suryono, and A.B. Abdullah. The distribution and abundance of Polychaeta in the mangrove area Klaces and Sapuregel, Segara Anakan. Center for Coastal and Marine Studies, Research Institute of Diponegoro University (2003b)

13. K.E. Carpenter, V.H. Niem, FAO s (FAO Library, 2001).

14. M.I. Effendie. Biologi Perikanan. Yayasan Pustaka Nusantara.. Yogyakarta. Pp. 163 (1997).

15. E.R. Ardli, A. Widyastuti, E. Yani. Kajian perubahan bioekologi pada restorasi mangrove di Segara Anakan Cilacap. Biosfera 32(1): 19-28. (2015)

16. J. Akbar, I.E. Bahtiar, . J. Mina Laut Indones. 4, 1-12 (2014) 